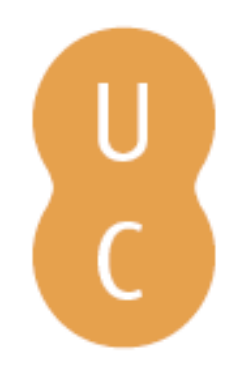

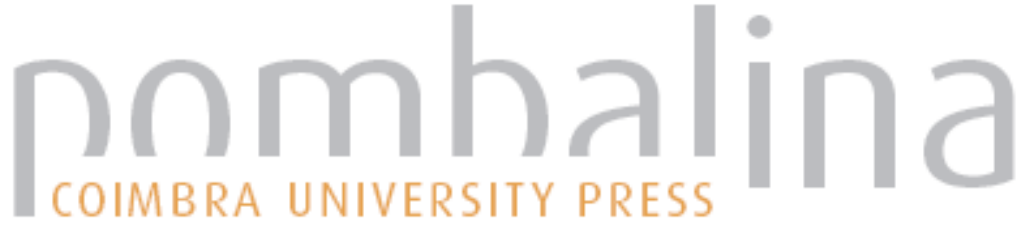

\section{Retratos dos Césares em Suetónio: do Eidos ao Ethos}

Autor(es): $\quad$ Brandão, José Luis Lopes

Publicado por: Imprensa da Universidade de Coimbra

URL

persistente:

URI:http://hdl.handle.net/10316.2/32565

DOI:

DOI:http://dx.doi.org/10.14195/978-989-26-0442-8_6

Accessed : $\quad$ 26-Apr-2023 10:04:05

A navegação consulta e descarregamento dos títulos inseridos nas Bibliotecas Digitais UC Digitalis, UC Pombalina e UC Impactum, pressupõem a aceitação plena e sem reservas dos Termos e Condições de Uso destas Bibliotecas Digitais, disponíveis em https://digitalis.uc.pt/pt-pt/termos.

Conforme exposto nos referidos Termos e Condições de Uso, o descarregamento de títulos de acesso restrito requer uma licença válida de autorização devendo o utilizador aceder ao(s) documento(s) a partir de um endereço de IP da instituição detentora da supramencionada licença.

Ao utilizador é apenas permitido o descarregamento para uso pessoal, pelo que o emprego do(s) título(s) descarregado(s) para outro fim, designadamente comercial, carece de autorização do respetivo autor ou editor da obra.

Na medida em que todas as obras da UC Digitalis se encontram protegidas pelo Código do Direito de Autor e Direitos Conexos e demais legislação aplicável, toda a cópia, parcial ou total, deste documento, nos casos em que é legalmente admitida, deverá conter ou fazer-se acompanhar por este aviso.

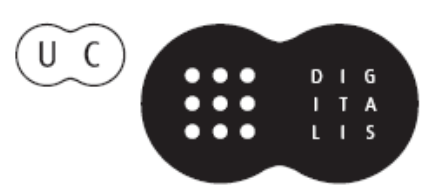


Aurelio Pérez Jiménez, Joșé Ribeiro Ferreira

e Maria do Céu Fialho

(COORdinadores)

\section{Adminiftri Principum.}

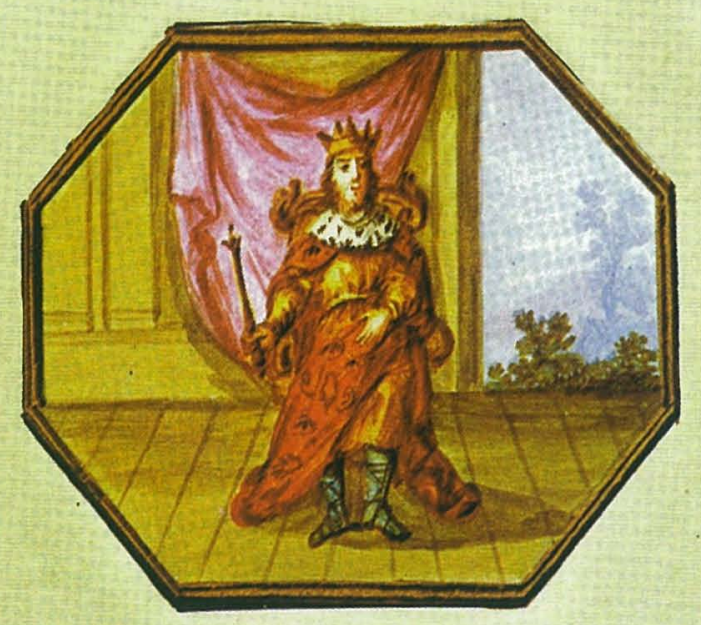

\section{EMBLEM A LIV.}

En tibi plura gerit, quàm lumina prabuit Argos Rex; Aures totidem, quin totidemó, manus. Hec opus Imperio, fidis fupplenda Minijtris, Regi bi funt aures: lumina clara, manus.

\section{- Retrato e a Biografia como estratégia de teorização política}

IMPRENSA DA UNIVERSIDADE DE COIMBRA

Universidad de MálaGa 
(Página deixada propositadamente em branco) 
Aurelio Pérez Jiménez

José RIBEIRo FERREIRA

Maria do Céu Fialho

O RETRATO LITERARIO E A BIOGRAFIA COMO ESTRATÉGIA

\section{DE}

TEORIZACCÃO POLITICA

IMPRENSA DA UNIVERSIDADE DE COIMBRA

UnIVERSIDAD DE MÁlaGa

2004 
Obra publicada com a colaboração de:

Centro de Estudos Clássicos e Humanísticos (Universidade de Coimbra)

International Plutarch Society

Primera edição, Junho de 2004

(c) IMPRENSA DA UnIVERSIDADE DE COIMBRA

(c) Área de Filología Griega. Universidad de Málaga

Coordenação editorial:

Imprensa da Universidade de Coimbra

Área de Filología Griega de la UMA

ISBN: 972-8704-25-9 (PORTUGAL)

ISBN: 84-608-0166-7 (ESPANHA)

Depósito Legal: MA-1420

Impresso em Espanha

Execução gráfica:

IMAGRAF IMPRESORES, S.A.

c/ Nabucco 14

29006 Málaga

Tfno. 952328597

Página de rosto:

"Dos Princepes Transùmptos verdadeiros": Francisco António Novaes Campos, Principe perfeito. Emblemas de D. Joâo de Solórzano. Edição fac-similada do manuscrito da Biblioteca Nacional do Rio de Janeiro oferecido ao Príncipe D. João em 1790 (Prefácio, introdução, comentário e índices por Maria Helena de Teves Costa Ureña Prieto), Instituto de Cultura e Língua Portuguesa, Lisboa, 1985, Emblema LIV, p. 114. 


\section{Retratos dos CÉSARES em Suetónio: DO EIDOS AO ETHOS}

José Luis Lopes Brandão

Universidade de Coimbra

Ao delinear o retrato físico dos Césares, Suetónio parece sugerir, embora de forma não sistemática, a aproximação entre o carácter e o aspecto exterior. Normalmente esta rubrica acontece, na estrutura das Vidas dos Césares, ou imediatamente antes ou imediatamente depois da narrativa da morte - o momento supremo da revelação do ethos. O retrato físico aparece como um suplemento de informação que cria na mente do leitor uma imagem visual, mais ou menos coerente com a personalidade do césar, ilustrada, com vários exemplos, ao longo da biografia. A consciência da relação entre o aspecto e o carácter é acentuada pelo facto de o biógrafo expressar surpresa, quando a aproximação não é possível. Depois de narrar a morte heróica de Otão, que se suicidou para pôr fim à guerra civil e evitar mais vítimas, começa assim a descrição física deste efémero imperador do ano 69: "A tão grande coragem não correspondia de forma alguma nem o físico nem os modos"

Há quem pense que Suetónio foi influenciado por teorias fisiognomónicas². É

* Quero expressar a minha gratidão ao Prof. Doutor Walter de Medeiros pela leitura deste trabalho e pelas oportunas sugestões que fez. Incorrecções que subsistam são da minha inteira responsabilidade.

1 Otho 12.1: Tanto Othonis animo nequaquam corpus aut habitus competit. Gascou, J. 1984, Suétone historien, Paris, de Boccard, 615 sustenta a preocupação de Suetónio com o realismo que acaba por servir de moderador: assim evita o exagero na sátira ou na idealização.

2 Cf. Evans, E. C. 1950, "Physiognomics in the Roman empire": CJ 45 277-282; Couissin, J. 1953, "Suétone physiognomoniste dans les vies des XII Césars": REL 31

A. Pérez Jiménez, J. Ribeiro Ferreira, Maria do Céu Fialho (edd), O retrato literário e a biografia como estratégia de teorização política, Coimbra-Málaga, 2004, pp. 83-114. 
muito provável que tais conceitos lhe não fossem estranhos. Mas o que o biógrafo parece querer sugerir é mais simples. Trata-se, por um lado, da adopção moderada do antigo preconceito de que o bom corresponde ao belo; e, por outro, da constatação de que certas deformidades ou traços grotescos são a consequência de desregramento moral. Não nos restringiremos aos pormenores meramente físicos, pois Suetónio geralmente acrescenta outros dados, relativos ao vestuário e cuidados corporais, que, com o retrato físico e as informações sobre a saúde, formam um todo. Procuraremos estabelecer o grau de correspondência entre imagem deixada na descrição directa e a imagem que decorre de cada Vida no seu todo, ilustrada com factos ou com ditos, com acontecimentos históricos ou anedóticos, com testemunhos fidedignos ou com rumores, como é, de resto, apanágio da biografia.

\section{Júlio César: a vaidade e a ambição desmedidas}

De César depreende-se uma imagem de beleza e perfeição física: "estatura elevada, tez clara, membros bem proporcionados, o rosto um pouco mais cheio ${ }^{3}$, olhos negros e vivos" $"$. Com efeito, gostava de apregoar a sua descendência de Vénus (6.1). A nota negativa está no zelo excessivo com o físico e revelador de um carácter efeminado: "com os cuidados corporais era bastante minucioso: não só punha todo o afinco a aparar o cabelo e a fazer a barba, mas até se depilava, na opinião de alguns. Suportava muito mal o defeito da calvície, por perceber que o expunha amiúde às brincadeiras dos seus detractores. Por isso, costumava recompor o cabelo em falta, puxando-o do alto da cabeça; e, de todas as honras que lhe foram decretadas pelo senado e pelo povo, nenhuma recebeu e usou com maior vontade do que o direito de usar sempre uma coroa de louros. Dizem que era digna de nota também a forma de vestir: usava a túnica laticlávia com franjas até às mãos e sobre ela se cingia sempre, deixando a cintura bastante folgada"5.

234-256; Stok, F. 1995, "Ritratti fisiognomici in Suetonio": Biografia e autobiografia degli antichi e dei moderni, a cura di Italo Gallo e Luciano Nicastri, Napoli, Ed. Scientifiche Italiane, 109-135. Para a crítica da aplicação destas teorias aos retratos suetonianos, cf. Gascou, J. 1984, Suétone historien, 592-616; Baldwin, B. 1983, Suetonius. Amsterdam, Hakkert, 498-501.

Couissin, J. 1953, "Suétone physiognomoniste", 242, pensa que ore paulo pleniore se refere não ao rosto, mas ao aspecto da boca. Gascou, J. 1984, Suétone historien, 598602, considera enigmático este traço (n. 534) .

Iul. 45.1: Fuisse traditur excelsa statura, colore candido, teretibus membris, ore paulo pleniore, nigris uegetisque oculis, ualitudine prospera...

5 Iul. 45.2-3: Circa corporis curam morosior, ut non solum tonderetur diligenter ac raderetur, sed uelleretur etiam, ut quidam exprobrauerunt, caluitii uero deformitatem 
Os membros bem feitos, associados aos olhos vivos, sugerem também a excepcional resistência física que faz dele um intrépido homem de acção, como provam as inúmeras e heróicas façanhas descritas (57-65). É um bom e austero general: muito comedido na bebida e totalmente indiferente em relação à comida (53). $\mathrm{O}$ carácter efeminado está de acordo com as acusações que lhe faziam de ter partilhado o leito de Nicomedes da Bitínia $(2 ; 49)$ : pelo que Baldwin sugere a imagem helénica do sodomita valoroso ${ }^{6}$.

As preocupações com a aparência e a susceptibilidade às críticas ao aspecto físico revelam uma vontade de seduzir, expressa nos fesceninos dos soldados durante o triunfo - "Homens da Urbe, guardem as vossas mulheres; trazemos connosco o adúltero careca. / $\mathrm{Na}$ Gália fornicaste o ouro; aqui recebeste um empréstimo"7. César teria chegado a pedir a um tribuno da plebe que propusesse, na sua ausência, uma lei a conceder-lhe o direito de tomar as mulheres que quisesse e quantas quisesse, para assegurar descendência. Suetónio termina esta rubrica generalizando: "Mas para que ninguém duvide de que alastrava a sua má fama quer de pederasta passivo, quer de adúltero, Curião pai, em determinado discurso, chama-lhe homem de todas as mulheres e mulher de todos os homens"

A imagem de César, sempre coroado de louros, tornava-o imperator perpétuo ${ }^{9}$, e proporcionaria a transição para concretizar as suas aspirações monárquicas (79), ambição detestável para um romano (e sobretudo para o senado), comprovada por facta e dicta que tornam justa a sua morte (76.1), e que é apresentada como a causa do assassínio de que foi vítima (80). Mas a coroa de louros é também o símbolo da progénie dos Césares, que acabará com Nero, como se acentua na introdução à vida

iniquissime ferret saepe obtractatorum iocis obnoxiam expertus. Ideoque et deficientem capillum reuocare a uertice adsueuerat et ex omnibus decretis sibi a senatu populoque honoribus non aliud aut recepit aut usurpauit libentius quam ius laureae coronae perpetuo gestandae. Etiam cultu notabilem ferunt: usum enim lato clauo ad manus fimbriato nec umquam aliter quam <ut> super eum cingeretur, et quidem fluxiore cinctura. Por isso Sula advertia os optimates de que se guardassem daquele jovem «mal cingido».

6

7 Iul. 51: Vrbani, seruate uxores: moechum caluom adducimus. / Aurum in Gallia effutuisti, hic sumpsisti mutuum.

8 Iul. 52.3: At ne cui dubium omnino sit et impudicitiae et adulteriorum flagrasse infamia, Curio pater quadam eum oratione omnium mulierum uirum et omnium uirorum mulierem appellat.

9 Como sugere, citando Carcopino, Martin R. 1991, Les douze Césars: du mythe à la réalité, Paris, Les Belles Lettres, 51-52. 
da Galba ${ }^{10}$, e de um novo tipo de designação da soberania à qual Júlio César dá o nome. Um dia em que a plebe o aclama como rex, ele, querendo afastar a infâmia, afirma que "é César, não rei"

\section{Quatro governantes louváveis: Augusto, Otão, Vespasiano, Tito}

$\mathrm{O}$ retrato físico de Augusto balança entre a imagem de estudada beleza e serenidade de um filho de $\mathrm{Apolo}^{12}$ e uma descrição mais realista, que parece representar o homem.

Do longo retrato ${ }^{13}$, sobressai a forma eximia, que se mantém uenustissima ao longo das várias fases da vida, apesar da negligência de Augusto em relação aos cuidados corporais; um ar calmo e sereno, que demove do seu propósito um agressor; os olhos vivos e brilhantes. O biógrafo sugere que ele cultivava esta imagem: pretendia fazer crer que possuía um quiddam diuini uigoris no olhar e gostava de fazer baixar os olhos aos interlocutores quasi ad fulgoris solis. Tal descrição remete para a ideia da ligação a Apolo, assimilado ao Sol, que o biógrafo transmite a propósito do nascimento:

Leio nos 'livros da dissertação sobre a natureza divina' de Asclepíades de Mendes que Ácia tinha vindo a uma cerimónia solene de Apolo a meio da noite, e, depois de colocada a liteira no templo, enquanto as restantes matronas dormiam, se deixou também adormecer; que, de súbito, uma serpente rastejou até junto dela e pouco depois se retirou; que Ácia, depois de acordar, se purificou, como se viesse da união carnal com o marido; e que imediatamente no corpo dela apareceu um sinal, como uma serpente tatuada,

Gal.1.1.

11 Cf. Iul. 79.2.

Aug. 79.2-3. Cf. Grimal, P., 1986. "Suétone historien dans la Vie d'Auguste": Rome. La littérature et l'histoire, Paris, École Fraçaise de Rome II, 729-738, especialmente 734.

Aug. 79.1-2: Forma fuit eximia et per omnes aetatis gradus uenustissima, quamquam et omnis lenocinii neglegens ... uultu erat uel in sermone uel tacito adeo tranquillo serenoque, ut quidam e primoribus Galliarum confessus sit inter suos, eo se inhibitum ac remollitum, quo minus, ut destinarat, in transitu Alpium per simulationem conloquii propius admissus in praecipitium propelleret. Oculos habuit claros ac nitidos, quibus etiam existimari uolebat inesse quiddam diuini uigoris, gaudebatque, si qui sibi acrius contuenti quasi ad fulgorem solis uultum summitteret; sed in senecta sinistro minus uidit; dentes raros et exiguos et scabros; capillum leuiter inflexum et subflauum; supercilia coniuncta; mediocres aures; nasum et a summo eminentiorem et ab imo deductiorem; colorem inter aquilum candidumque; staturam breuem. 
e que nunca mais conseguiu retirar, a ponto de, posteriormente, se abster dos banhos públicos para o resto da vida. No décimo mês nasceu Augusto e, devido àquele acontecimento, foi considerado filho de Apolo. A mesma Ácia, antes de dar à luz, sonhou que as suas entranhas eram elevadas aos astros e se estendiam a toda a volta da terra e do céu. Também o pai, Octávio, sonhou que do ventre de Ácia saía a luz do sol ${ }^{14}$.

À imagem ideal, seguem-se pormenores mais realistas: o olho esquerdo mais fraco com a idade, os dentes ralos, pequenos e irregulares, o cabelo levemente ondulado e a tender para o louro, as sobrancelhas ligadas, as orelhas pequenas, o nariz alto no meio e curvado para baixo, a carnação entre o castanho (aquilus) ${ }^{15}$ e o branco; uma statura breuis, que a commoditas et aequitas membrorum fazem parecer maior. Suetónio nota a contradição entre pequena estatura e os cinco pés e três quartos $(1.70 \mathrm{~m})$ indicados por Júlio Márato, biógrafo de Augusto. Com efeito, Suetónio diz em outro passo (73) que Augusto usava sapatos altos, para parecer maior. Fica bem patente o esforço do imperador para alardear uma imagem de aparato, concretizada na conhecida estátua da Porta Prima ${ }^{16}$.

O retrato do homem, por oposição ao deus, é dado também pelas deformidades (fraqueza da perna esquerda; problemas no dedo indicador da mão direita; pedra na bexiga) (80). De facto, trata-se de um deus com pés de barro: pendem sobre ele acusações de sodomia (68), adultérios (68), esbanjamentos (70), vício do jogo (71.2),

14 Aug. 94.4: In Asclepiadis Mendetis Theologumenon libris lego, Atiam, cum sollemne Apollinis sacrum media nocte uenisset, posita in templo lectica, dum ceterae matronae dormirent, obdormisse; draconem repente irrepsisse ad eam pauloque post egressum; illam expergefactam quasi a concubitu mariti purificasse se; et statim in corpore eius extitisse maculam uelut picti draconis nec potuisse umquam exigi, adeo ut mox publicis balineis perpetuo abstinuerit; Augustum natum mense decimo et ob hoc Apollinis filium existimatum. Eadem Atia, prius quam pareret, somniauit intestina sua ferri ad sidera explicarique per omnem terrarum et caeli ambitum. Somniauit et pater Octauius utero Atiae iubar solis exortum. Cf. Díon Cássio 45.1. Apolo opõe-se a Dioniso a quem António está ligado, cf. Néraudau, J.-P. 1996, Auguste. La brique et le marbre, Paris, Les Belles Lettres, 121.

15 Couissin, J. 1953, "Suétone physiognomoniste", 244-246, pensa que o uso do termo aquilus não é fortuito: acompanhado da referência ao nariz aquilino e às sobrancelhas juntas, pretende associar Augusto à águia, não só em sentido fisiognomónico, mas também devido ao simbolismo que a ave tem para um romano. Para Gascou, J. 1984, Suétone historien, 602-606, Augusto não é aguia nem leão: é apolíneo.

Para Martin, R. 1991, Les douze Césars: du mythe à la réalité, Paris, Les Belles Lettres, 53, os sinais corporais em forma da ursa (Aug. 80.1), em paralelo com os sinais de sua mãe Ácia, contribuem para a formação do mito. 
em grande parte resultantes da invectiva política de António. Mas a abordagem de Suetónio procura desculpar estes vícios e acentuar as virtudes, ${ }^{17}$ descritas a seguir e imediatamente antes do retrato físico e dos seus hábitos. A imagem que prevalece é de austeridade (72), parcimónia (73), amabilidade (74), liberalidade (75), extrema moderação na comida (76) e no vinho (77). O biógrafo também lhe perdoa o facto de ter sido um jovem cruel, visto que tal propensão foi compensada pela fundação do nouus status (28.2) e pelo seu bom governo. A vida que começou com guerras termina em paz: no seu leito de morte, o velho imperador pergunta se representou bem o mimo da vida e pede o aplauso habitual no fim das representações (99.1).

O retrato do fundador da dinastia dos Flávios, Vespasiano, é bastante favorável ${ }^{18}$ e está em consonância com o seu carácter. $\mathrm{O}$ aspecto faz apelo à força do general (como é apresentado em 4.6): tinha uma estatura bem proporcionada, com membros sólidos e rijos. A característica expressão do rosto de quem está a fazer esforço associa-se a uma faceta largamente ilustrada nesta biografia: o sentido de humor. Vespasiano pediu a um brincalhão que dissesse algo espirituoso acerca do próprio governante e o interlocutor respondeu-lhe que diria "quando o imperador deixasse de aliviar a tripa". Nem na hora da morte Vespasiano perde o sentido de humor e, aludindo a futura divinização, exclama: «Ai! Julgo que me estou a tornar um deus!» (23.4). É curioso que Suetónio omita a calvície, mencionada por Díon Cássio (66.17.3), como se o biógrafo quisesse poupar o simpático imperador a esta deficiência incómoda para um romano, e que outros (César, Otão) procuravam disfarçar. Ciuilis et clemens (12), o seu único defeito é a pecuniae cupiditas (16.1). Mas logo se acrescenta em seu favor que foi liberalissimus com todas as classes (17).

Também o retrato do filho de Vespasiano, Tito, é bastante positivo ${ }^{19}$ : dotes de corpo e dotes da alma brilharam desde criança. Apresentava forma egregia, a auctoritas igualava a gratia e tinha grande robustez, apesar de ser de pequena estatura e ter o ventre algo proeminente. Tal retrato está de acordo com a sentença de abertura da breve biografia: Tito era amor ac deliciae generis humani (1) e natura autem beniuolentis-

${ }_{17}$ Aug. 72.1: In ceteris partibus uitae continentissimum constat ac sine suspicione ullius uitii. 18 Vesp. 20.1: Statura fuit quadrata, compactis firmisque membris, uultu uelut nitentis; de quo quidem urbanorum non infacete siquidem petenti, ut et in se aliquid diceret: dicam, inquit, 'cum uentrem exonerare desineris'.

19

Tit. 3.1: In puero statim corporis animique dotes explenduerunt, magisque ac magis deinceps per aetatis gradus: forma egregia et cui non minus auctoritatis inesset quam gratiae; praecipuum robur, quamquam neque procera statura et uentre paulo proiectiore. Cf. Tácito, Hist. 2.1.4. 
simus (8). A ressalva feita ao ventre sugere o seu lado negro: o gosto das orgias (7). A indicação da especial robustez que lhe permitia ser armorum et equitandi peritissimus (3.2) poderá também associar-se à violência e à inciuilitas (6.1). Atitudes violentas fazem com que chegue ao trono com má reputação sem-par (6.2). Mas, ao tornar-se imperador, mudou os vícios em virtudes (7.1), ao ponto de rejeitar Berenice por razões de estado, contra a sua vontade e contra a vontade dela (7.2). A sua morte é maior prejuízo para a humanidade do que para o próprio (10.1). Como Tito diz, morre sem o merecer, uma vez que lhe não pesa na consciência senão um acto (10.1).

Em oposição aos retratos que acabamos de referir, surge o retrato físico de Otão. Suetónio, certamente influenciado pelo pai, Suetónio Leto, que militara no exército deste imperador, mostra, ao contrário do senador Tácito, grande simpatia por Otão, mas observa que tanto o físico como os hábitos contrastam, surpreendentemente, como dissemos, com a grandeza do seu suicídio. O retrato físico é apenas esboçado: "de pequena estatura, tem pés deformados e é cambaio". Também os costumes efeminados tornam surpreendente a virilidade demonstrada na morte: depilava-se e, como tinha o cabelo ralo, usava uma peruca, mas tão bem adaptada que ninguém dava conta; barbeava-se diariamente e aplicava sobre a face um bocado de pão humedecido; participava publicamente nos mistérios de Ísis, vestido, como os sacerdotes da deusa, com um hábito de linho ${ }^{20}$. É o oposto da imagem de um hirsuto estóico. Já na altura em que se rebela contra Galba, é digno de nota que se dirija para o campo pretoriano escondido numa liteira de mulher ${ }^{21}$. O biógrafo pretende acentuar o miraculum que foi a sua morte: "é por este facto que julgo que a morte dele, de modo algum consonante com a vida, causou maior espanto"22.

A sua vida estava longe de ser exemplar. Pródigo e licencioso desde a primeira juventude, o pai tinha de o corrigir a golpes de chicote (2.1). Conseguiu facilmente o primeiro lugar entre os amigos de Nero: "pela compatibilidade de hábitos, e ainda,

Otho 12.1: Tanto Othonis animo nequaquam corpus aut habitus competit. Fuisse enim et modicae staturae et male pedatus $<s>$ cambusque traditur, munditiarum uero paene muliebrium, uulso corpore, galericulo capiti propter raritatem capillorum adaptato et adnexo, ut nemo dinosceret; quin et faciem cotidie rasitare ac pane madido linere consuetum, idque instituisse a prima lanugine, ne barbatus umquam esset; sacra etiam Isidis saepe in lintea religiosaque ueste propalam celebrasse.

21 Otho 6.3: abditus propere muliebri sella. Tácito (Hist. 1.27.2) diz só et sella festinanter impositum.

22 Otho 12.2: per quae factum putem, ut mors eius minime congruens uitae maiore miraculo fuerit. 
como alguns dizem, por recíprocas relações carnais" ${ }^{23}$. A paixão comum por Popeia Sabina põe fim à amizade e determina o envio de Otão para a Lusitânia: um exílio com a aparência de cargo administrativo (3.1-2). Mesmo assim, tornado imperador, não rejeita o apelido de Nero, segue uma política filoneroniana (7.1) e manifesta a intenção de casar com a viúva do antigo amigo, Estatília Messalina, a quem, à beira da morte, envia uma carta a recomendar-lhe os seus restos e a memória (10.2).

O mérito de Otão está no ódio às guerras civis, que só Suetónio menciona. Para evitar mais derramamento de sangue opta pelo suicídio, quando nem tudo estava perdi$\mathrm{do}^{24}$. O biógrafo absolve-o da morte de Galba, considerada facinus flagitiosissimum por Tácito (Hist. 2.50.1): movia-o a boa intenção de restituir a libertas ao estado (12.2).

\section{Entre o bem e o mal: Cláudio, vítima da distorção cómica}

O retrato físico de Cláudio é reflexo da descrição paradoxal que dele faz Suetónio: uma alternância contínua de aspectos positivos e negativos: "Não lhe faltava autoridade nem dignidade no aspecto físico, quer de pé, quer sentado e sobretudo em repouso. Tinha, de facto, uma estatura elevada sem ser descarnado, uma bela face e uma bela cabeleira branca, um pescoço forte. Quanto ao resto, ao caminhar, traíam-no os jarretes pouco firmes e, quer tratasse de assuntos ligeiros, quer de assuntos graves, muitos eram os aspectos grotescos: um riso desagradável; uma fúria ainda mais repugnante, com o espumar da boca; o nariz a pingar; além do mais, uma voz entaramelada e a cabeça sempre a tremer, sobretudo quando fazia esforço, por pequeno que fosse" 25 .

23 Otho 2.2: ... congruentia morum, ut quidam tradunt, et consuetudine mutui stupri, Díon Cássio, 64.8, confirma a homossexualidade de Otão, mas com os favoritos de Nero: cf. Martin R. 1991, Les douze Césars: du mythe à la réalité, 166.

Otho 9.3; Marcial regista com admiração o mesmo facto (6.32).

Cl. 30: Auctoritas dignitasque formae non defuit ei, uerum stanti uel sedenti ac praecipue quiescenti, nam et prolixo nec exili corpore erat et specie canitieque pulchra, opimis ceruicibus; ceterum et ingredientem destituebant poplites minus firmi, et remisse quid uel serio agentem multa dehonestabant: risus indecens, ira turpior spumante rictu, umentibus naribus, praeterea linguae titubantia caputque cum semper tum in quantulocumque actu uel maxime tremulum [Preferimos a correcção, adoptada por Ailloud, de uerum em vez de et ueterum do manuscrito $M$, seguido, com uma crux desperationis, por Ihm.] Estes traços são ainda mais caricaturados em Séneca, Apoc. 5.2-3. Cf. Martin R. 1991, Les douze Césars: du mythe à la réalité, 70-74. Gascou, J. 1984, Suétone historien, 615, é de opinião que: "Ici, Suétone s'abandonne à sa veine caricaturale et délaisse toute objectivité, comme l'indiquent les termes méprisants qu'il accumule (dehonesta- 
A primeira parte deste retrato reflecte a eugeneia, que se manifesta, como o próprio Augusto reconhece, quando o seu espírito se não perturba e quando lê em público ${ }^{26}$. De facto, o biógrafo refere positivas reformas religiosas, jurídicas e sociais (22-25). Mas, quando entra em crise, Cláudio perde a compostura e torna-se ridículo: perante a recusa dos naumachiarii em combaterem, desata a correr de um lado para o outro, à beira do lago Fúcino, com um desagradável coxear (non sine foeda uacillatione discurrens), enquanto os ameaça e exorta ao combate ${ }^{27}$.

A segunda parte do retrato - uma caricatura do ser aberrante - surge em consonância com a imagem de um homem totalmente inepto para o cargo que irá ocupar, como vem sendo salientado desde o início desta Vida: fora afastado, desde a infância, pela família, dos olhares públicos; entregara-se à bebida e ao jogo dos dados, como em perpétuas Saturnais, na companhia de pessoas de vil categoria, no tempo de Tibério, e tornara-se objecto de troça na corte, durante o governo de Calígula. Diz o biógrafo, depois de referir alguns sinais auspiciosos para Cláudio no início do principado do sobrinho:

Nem por isso estava menos exposto a afrontas. De facto, se chegava um pouco mais tarde do que a hora prevista para o jantar, não era sem custo que, depois de dar a volta ao triclínio, se instalava e, cada vez que adormecia depois de comer, facto que normalmente acontecia, atiravam-lhe caroços de azeitonas e de tâmaras. Por vezes era acordado pelos bobos a golpes de palmatória ou de chicote, como se faz na escola. Enquanto ressonava, costumavam calçar-lhe socas nas mãos, para que, ao despertar de repente, esfregasse a cara com elas" 28 .

A inversão de papéis é uma constante ao longo da vida. A narrativa da aclamação apresenta Cláudio aterrorizado (como demonstram as expressões: exterritus; prae metu, tristis ac trepidus; minor spe quam fiducia) e as suas reacções são ridículas e

bant, indecens, turpior). Il ne manie plus les instruments du clinicien, mais le fouet de la satire." Cf. Stok, F. 1995, "Ritratti fisiognomici in Suetonio", 129.

26

27

28

Cl. 4.5 .

Cl. 21.6.

Cl. 8: Nec eo minus contumeliis obnoxius uixit. Nam et si paulo serius ad praedictam cenae horam occurrisset, non nisi aegre et circuito demum triclinio recipiebatur, et quotiens post cibum addormisceret, quod ei fere accidebat, olearum aut palmularum ossibus incessebatur, interdum ferula flagroue uelut per ludum excitabatur a copreis. Solebant et manibus stertentis socci induci, ut repente expergefactus faciem sibimet confricaret. Cf. Guastella, G. 1999, Gaio Svetonio Tranquillo. L'imperatore Claudio (testo, trad. e comm.), a cura di -, Venezia, Marsilio, 36. 
ignominiosas para um futuro imperador: perante a notícia da morte de Calígula, rasteja (prorepsit), esconde-se atrás de um reposteiro (interque praetenta foribus uela se abdidit), mas fica com os pés de fora (animaduersis pedibus). Descoberto, lança-se, com o gesto tradicional de súplica, aos joelhos do soldado (ad genua sibi adcidentem) - pormenor que só figura em Suetónio. E tratava-se de um miles gregarius, o que acentua a inversão de papéis ${ }^{29}$.

Suetónio adopta a distorção própria da comédia. Cláudio é apresentado como um senex de palliata submetido a mulheres e a libertos ${ }^{30}$. Estes tomam por ele as decisões boas e más. Cláudio comporta-se, não como um princeps, mas como minister $^{31}$; e, como seria de esperar, surge a situação caricata e trágica de se não lembrar de ter dado a ordem de execução de um antigo cônsul ${ }^{32}$. Está presente o topos de comédia do amante ludibriado que entrega a mulher, como o Pirgopolinices de Plauto, em troca de um benefício:

Na verdade, o caso seguinte terá excedido toda a credibilidade, pois nas núpcias, que Messalina celebrou com o adúltero Sílio, o imperador terá sido induzido a assinar, por sua própria mão, as tabuinhas do dote, como se fossem propositadamente simuladas, para desviar e transferir para outrem o perigo que, pelo que alguns fenómenos pressagiavam, estava a ponto de cair sobre $\mathrm{ele}^{33}$.

Cl. 10. Cf. Díon Cássio 60.12-3 e Flávio Josefo, AJ. 19.212-225. Cf. Guastella, G. 1999, Gaio Svetonio Tranquillo. L'imperatore Claudio, 37-38, e Gascou, J. 1984, Suétone historien, 428-430, que afirma: "L'insignificance de la cause de l'élévation de Claude correspond à l'insignifiance du personnage (aux yeux de son biographe) et cette façon de présenter les choses relève moins d'une conviction profonde sur le rôle du hasard en histoire que de la technique du pamphlétaire" (p.430).

Cl. 29.1

Cl. 29.3: Nam illud omnem fidem excesserit quod nuptiis, quas Messalina cum adultero Silio fecerat, tabellas dotis et ipse consignauerit, inductus, quasi de industria simularentur ad auertendum transferendumque periculum, quod imminere ipsi per quaedam ostenta portenderetur. Tácito (Ann. 11.27.1) descreve um rito matrimonial segundo as regras, mas não menciona envolvimento de Cláudio na assinatura do contrato. Narciso informa o imperador e aconselha-o a obrigar Sílio a rasgar o contrato e a restituir a mulher. Ora Suetónio afirma a aprovação de Cláudio ao casamento, cf. Guastella, G. 1999, Gaio Svetonio Tranquillo. L'imperatore Claudio, 199. Em Plauto, no Miles gloriosus, Pirgopolinices, induzido por Palestrião (vv. 973-984 e 1094-1136), cede de boa vontade Filocomásio ao amante, com os seus haveres e o escravo (vv. 1311-1377), em vista da posse da esposa do vizinho (que na realidade era solteiro). Mas, de modo diverso de 
A característica credulidade do senex é divertida numa comédia de Plauto, mas, quando este senex é imperador, o resultado pode ser trágico:

Contam que assim foi morto Ápio Silano. Como Messalina e Narciso conspiravam para o liquidar, dividiram os papéis: Narciso, com ar estupefacto, irrompeu, antes da aurora, pelo quarto do patrono a dizer que sonhara que Ápio usava da força contra Cláudio; Messalina, fingindo admiração, contou que a mesma visão lhe surgia há já algumas noites. Não muito depois, conforme fora concertado, anunciaram ao imperador que irrompia Ápio, a quem se recomendara, no dia anterior, que se apresentasse naquele momento. Como se a veracidade do sonho se tornasse totalmente evidente, Cláudio mandou acusá-lo e executá-lo. E não hesitou em relatar no dia seguinte ao senado o completo desenrolar dos acontecimentos e dar graças ao liberto, que até a dormir velava pela sua segurança ${ }^{34}$.

O ludíbrio de Cláudio através de um suposto sonho tem correspondência em enredos da palliata ${ }^{35}$. Se já é objecto de riso contar a história do seu engano no senado, como se de um grande feito se tratasse, o cúmulo da farsa é agradecer publicamente a quem o enganou ${ }^{36}$. Tal inversão só tem paralelo na cena final do Epídico de Plauto. $\mathrm{O}$ biógrafo parece mesmo sugerir o topos do senex iratus, pois introduz de seguida o tema da ira atque iracundia ilustradas com exemplos caricatos de cólera (38.1-2).

Plauto, em Suetónio há adultério pelo meio e personagens moralmente reprováveis - o que para Guastella, G. 1999, 43-44, acarreta um efeito que não é meramente cómico.

Cl. 37.2: Pari modo oppressum ferunt Appium Silanum: quem cum Messalina et Narcissus conspirassent perdere, diuisis partibus alter ante lucem similis attonito patroni cubiculum inrupit, affirmans somniasse se uim ei ab Appio inlatam; altera in admirationem formata sibi quoque eandem speciem aliquot iam noctibus obuersari rettulit; nec multo post ex composito inrumpere Appius nuntiatus, cui pridie ad id temporis ut adesset praeceptum erat, quasi plane repraesentaretur somnii fides, arcessi statim ac mori iussus est. Nec dubitauit postero die Claudius ordinem rei gestae perferre ad senatum ac liberto gratias agere, quod pro salute sua etiam dormiens excubaret.

35 Como sublinha Guastella, G. 1999, Gaio Svetonio Tranquillo. L'imperatore Claudio, 910 e 33-34, trata-se do engano de um senex pela arteirice de um libertus fallax e uma matrona (ou uma meretrix, dado o conceito que Suetónio tem de Messalina). Além disso, há uma nítida semelhança com uma cena do Miles gloriosus de Plauto, vv. 370-410: Palestrião, com base num suposto sonho de Filocomásio sobre o aparecimento de uma irmã gémea, convence o medroso Céledro de que não vira Filocomásio na casa do vizinho, mas a tal gémea.

O facto de Cláudio dizer que Narciso até durante o sono velava, poderá ser uma forma hiperbólica de agradecimento pelos serviços do liberto, proferida em qualquer altura pelo imperador e aproveitada por fontes hostis. 
A ligação à comédia é acentuada ainda pelo comportamento báquico, onde ficam bem patentes os excessos, nas mulheres e no jogo, caricaturados pelo recurso a superlativos (cibi uinique... appetentissimus, somni breuissimi, libidinis in feminas profusissimae; aleam studiosissime lusit) ${ }^{37}$. Cláudio é apresentado como um glutão: o odor de uma refeição dos Sálios leva-o a abandonar o tribunal. Habitualmente, adormecia deitado de costas e de boca aberta, empanturrado e encharcado em vinho (distentus ac madens), e tinham de lhe introduzir uma pena na boca para aliviar o estômago ${ }^{38}$. Corria até o boato de que tinha em mente promulgar um edicto a dar licença para a libertação de gases à mesa ${ }^{39}$. Estamos perante a cedência a um recurso farsesco bem conhecido da comédia, já criticado por Aristófanes nas Nuvens ${ }^{40}$.

Ao retrato físico grotesco corresponde o psíquico de um incapaz para a função: um stultus (38.3), que convoca pessoas que mandara executar e faz observações completamente despropositadas (39-40). Depois de transcrever algumas, Suetónio conclui: "estas e muitas outras saídas da mesma sorte, degradantes até para um particular, quanto mais para um príncipe a quem não faltava nem eloquência nem cultura, e que, bem pelo contrário, se entregava mesmo com afinco aos estudos liberais" ${ }^{, 41}$.

Na cena da morte, continua a deformação cómica por apelo ao dolo, à gula e a motivos escatológicos. $\mathrm{O}$ gosto de Cláudio pelos banquetes tornam credível um envenenamento, como se deduz das versões apresentadas sobre este conhecido exitus (44). Sobre o momento e o agente do crime são apresentadas duas versões: o veneno fora ministrado ou pelo provador oficial, o eunuco Haloto, ou pela própria

$C l$. 33. Destoa, pelo carácter positivo, a nota de que se abstém do comércio com homens: marum omnino expers. No que diz respeito ao gosto pelo jogo, a comparação com Aug. 71.1-3 mostra que Suetónio é tendencioso; cf. Guastella, G. 1999, Gaio Svetonio Tranquillo. L'imperatore Claudio, 202-203.

$\mathrm{Cl}$. 33.1. A pena será o meio usado no seu assassínio, para introduzir a segunda dose de veneno, segundo a versão da morte transmitida por Tácito, Ann. 12.67. 2.

$C l$. 32. Mais uma vez se trata de uma anedota colhida em fontes orais. Autorização semelhante é também concedida aos convidados por Trimalquião: Petrónio, 47.5-6, cf. Ferreira, P. S. 2000, Os elementos paródicos no Satyricon de Petrónio e o seu significado, Coimbra, Colibri / Faculdade de Letras, 81 e 129-130. Séneca, Apoc. 4.3, explora este argumento: Vltima uox eius haec inter homines audita est, cum maiorem sonitum emisisset illa parte qua facilius loquebatur: 'Vae me, puto, concacaui me'.

Vv. 293-296. Cf. Silva , M. F. 1987, Crítica do teatro na comédia antiga, Coimbra, Gulbenkian / JNICT, 87-89.

41 Cl. 40.3: Multaque talia etiam priuatis deformia, nedum principi, neque infacundo neque indocto, immo etiam pertinaciter liberalibus studiis dedito. 
Agripina, num cogumelo, pois Cláudio era auidissimus ciborum talium ${ }^{42}$. Suetónio apresenta também duas variantes para o subsequente desenrolar dos acontecimentos. A falta de dignitas que marcou a vida deste imperador continua presente, de modo particular, na segunda versão relatada: Cláudio adormece, como é seu hábito, depois vomita tudo e tem de se repetir a dose de veneno em umas papas, com a desculpa de que precisava de se refazer com mais comida, ou num clister, por se encontrar obstipado e ter necessidade deste meio para evacuar ${ }^{43}$.

\section{Quatro imperadores perversos: Tibério, Galba, Vitélio, Domiciano}

Quanto a Tibério, Suetónio deixa-nos uma positiva imagem física de robustez ${ }^{44}$, consentânea com a do áustero comandante militar que ele fora (18). A estatura a exceder o normal parece sugerir desequilíbrio. Por outro lado, a proporcionalidade de membros encontra correspondência na fase positiva do início do reinado, antes de se retirar para a ilha de Cápreas. A mão esquerda é mais forte, com as articulações tão firmes que, com os nós dos dedos, seria capaz de furar uma maçã acabada de colher ou ferir na cabeça, com um piparote, uma criança ou até um adolescente. Tal precisão realista ${ }^{45}$ - e nenhum outro autor refere esta particularidade sugere uma experiência feita, que recorda a pederastia de Tibério ${ }^{46}$, associada à cru-

Cl. 44.2. A versão do envenenamento parece ser, na época, geralmente aceite. Só Flávio Josefo, AJ 20.151, manifesta dúvidas. Comparação das várias fontes sobre a morte de Cláudio em Gascou, J. 1984, Suétone historien, 281-293; Baldwin, B. 1983, Suetonius, 164-165; Questa, C. 1959, "La morte di Augusto secondo Cassio Dione": PP. 14 41-55, especialmente $46-48$.

Cl. 44.3 .

Tib. 68.1-2: Corpore fuit amplo atque robusto, statura quae iustam excederet; latus ab umeris et pectore, ceteris quoque membris usque ad imos pedes aequalis et congruens; sinistra manu agiliore ac ualidiore, articulis ita firmis, ut recens et integrum malum digito terebraret, caput pueri uel etiam adulescentis talitro uulneraret. Colore erat candido, capillo pone occipitium summissiore ut ceruicem etiam obtegeret, quod gentile in illo uidebatur; facie honesta, in qua tamen crebri et subiti tumores, cum praegrandibus oculis et qui, quod mirum esset, noctu etiam et in tenebris uiderent, sed ad breue et cum primum e somno patuissent; deinde rursum hebescebant. Incedebat ceruice rigida et obstipa, adducto fere uultu, plerumque tacitus...

Cf. Gascou, J. 1984, Suétone historien, 611-612, n. 582.

Cf. Lindsay, H. 1995, Suetonius, Tiberius, edited with introduction, commentary and bibliography by —- London, Bristol Classical Press, (intr.) 17. Pelo contrário, Martin R. 1991, Les douze Césars: du mythe à la réalité, 60, acha que se não deve interpretar como sinal de crueldade. 
eldade: viola o ministro de um sacrifício e o irmão e manda quebrar as pernas aos dois (44.2). Mas a força da sinistra manus pode também sugerir outras características de Tibério: a avareza (ilustrada nos caps. 46-48) e a tendência para a rapina (49) - basta lembrar o mau uso que o ladrão de guardanapos de Catulo fazia da mão esquerda ${ }^{47}$. Mesmo no momento da morte, Tibério tira o anel para transmitir o seu poder, mas logo se arrepende e o retém, compressa sinistra ${ }^{48}$.

Diz também o biógrafo que Tibério tinha o cabelo plantado até abaixo por detrás da cabeça, o que parecia uma característica da família. A carga hereditária tem para o biógrafo grande peso no carácter dos Césares e na biografia de Tibério a influência é notória ${ }^{49}$. Ora na descrição da família cláudia, com que Suetónio abre esta biografia, embora se diga que há muitas obras meritórias e muitas más ${ }^{50}$, prevalecem os aspectos negativos. A observação de que possuía uma facies honesta, é ensombrada (com um tamen) pelos numerosos e súbitos tumores ${ }^{51}$. À afirmação de que tinha os olhos muito grandes ${ }^{52}$ se acrescenta um dado sinistro: a capacidade de ver de noite, que contribuiria para o tornar mais temido ${ }^{53}$.

A transição para o retrato psicológico faz-se através da referência à forma de caminhar de Tibério, com o pescoço rígido e inclinado para trás, e ao ar calado: atitudes desagradáveis e cheias de arrogância que Augusto desculpara como vícios da natu$r a$ e não do animus $^{54}$, imputando-os assim à hereditariedade. Fica sugerida a tendência para o isolamento, que o leva a dois auto-exílios: em Rodes, durante o governo de Augusto; e, na segunda parte do seu principado, em Cápreas. Tal misantropia é agravada pelo medo contínuo em que vivia ${ }^{55}$ e que o faz escolher Cápreas pela sua

47

48

49

50

Tib. 2.1: Multa multorum Claudiorum egregia merita, multa etiam sequius admissa in rem p. extant.

51 Tácito, que apresenta o retrato mais negativo de um Tibério mais velho (Ann. 4.57.2), fala de ulcerosa facies.

52

53

Tal acuidade demorava pouco tempo e sucedia ao despertar do sono. Esta fama pode ter sido divulgada pelo próprio Tibério, temeroso de atentados nocturnos, cf. Martin $\mathrm{R}$. 1991, Les douze Césars: du mythe à la réalité, 63-64.

54

55

Que, segundo Martin R. 1991, Les douze Césars: du mythe à la réalité, 62-63, pode ser sinal de miopia, o que explica a fraqueza de vista referida por Díon Cássio, 57.2.4.

Tib. 68.3.

Tib. 63.1: non modo inuisus ac detestabilis, sed praetrepidus quoque atque contumeliis obnoxius uixerit. 
inacessibilidade ("porque só uma pequena praia lhe facultava acesso, cercada como estava, por todos os lados, de rochas de altura imensa e de um mar profundo") ${ }^{56}$. O medo é ainda expresso na punição bárbara de um pescador que se dera ao trabalho de subir as escarpas para lhe oferecer o melhor peixe que pescara, mas, com a proeza, o deixara territus, ao revelar, assim, a vulnerabilidade do refúgio (60). Diz-nos o biógrafo que manifestou desde a infância uma saeua ac lenta natura, que leva o seu preceptor de retórica a denominá-lo como "barro amassado em sangue", mas que Tibério soube dissimular sob uma capa de moderação no início do seu governo ${ }^{57}$. Assim considera o biógrafo a parte boa do reinado deste imperador: fingimento, que acaba com a retirada para a ilha de Cápreas. Aí se entrega livremente a toda a espécie de vícios ${ }^{58}$ : bebida, luxúria, a ponto de lhe chamarem caprineus (43) e velho bode (45). A natura saeua leva-o a dizimar a família e os que lhe estão próximos. Por fim, mostra-se profundamente desgostoso de si próprio (67).

De Galba, diz Suetónio que "tinha uma estatura normal, a cabeça era completamente calva, os olhos de um azul carregado, o nariz aquilino, as mãos e pés completamente deformados devido à gota (articularis morbus), ao ponto de não suportar calçado nem conseguir desenrolar um bilhete ou segurá-lo sequer. Apareceralhe do lado direito uma excrescência de carne pendente e tão grande que a custo a continha com uma faixa" ${ }^{, 59}$.

Como no caso dos outros imperadores do ano 69, que antecederam Vespasiano, este retrato aparece na sequência da narrativa da morte e em íntima ligação com esta. Depois da statura iusta, os pormenores são quase todos negativos. A calvície, que envergonhava um romano e que César e Otão procuram dissimular, em Galba é total (capite praecaluo). Esta nota explicará um pormenor macabro que tinha sido

Tib. 40: ... quod uno paruoque litore adiretur, saepta undique praeruptis immensae altitudinis rupibus et profundo mari[s]. Em Tácito, Ann. 4.67.2, à inacessibilidade se junta

57

58

59 o clima temperado e a beleza do lugar.

Tib. 57.1.

Tib. 42.1: Ceterum secreti licentiam nanctus et quasi ciuitatis oculis remotis, cuncta simul uitia male diu dissimulata tandem profudit: de quibus singillatim ab exordio referam. A ideia da mudança na conduta é como que um cliché na tradição sobre os imperadores da dinastia júlio-claudiana; cf. Giua, M. A. 1975, "Tiberio simulatore nella tradizione storica pretacitiana": Athenaeum 53 352-363.

Gal. 21: Statura fuit iusta, capite praecaluo, oculis caeruleis, adunco naso, manibus pedibusque articulari morbo distortissimis, ut neque calceum perpeti neque libellos euoluere aut tenere omnino ualeret. Excreuerat etiam in dexteriore latere eius caro praependebatque adeo ut aegre fascia substringeretur. 
referido atrás: o soldado que lhe cortou a cabeça, "porque não podia agarrar-lhe pelo cabelo, escondeu-a no regaço; depois, metendo-lhe o polegar pela boca dentro, levou-a a Otão" ${ }^{\text {60 }}$. Permite ainda explicar a troça dos soldados, quando, ao passearem a cabeça do velho imperador na ponta de um pau, repetiam: "Galba, Amorzinho, goza a tua juventude!"61, e a razão do ridículo em que o ancião caía, ao afirmar que as suas forças ainda estavam intactas. $O$ retrato físico contrasta com o do excelente general que fora em tempos, capaz de restabelecer a disciplina no exército da Germânia (6.2), de dirigir os exercícios militares e correr ao lado do carro de Calígula numa distância de vinte mil passos (6.3) e de atrair as solicitações de Agripina (5) (se bem que não seriam só, nem principalmente, os atributos físicos de Galba a moverem esta ambiciosa mulher). Trata-se, pois, do retrato do imperador na sua velhice, porque Galba chegou tardiamente ao poder. Tácito diz-nos que a "sua velhice era objecto de troça para as pessoas habituadas à juventude de Nero e que comparam os imperadores, como é costume do vulgo, com base na beleza e graciosidade do físico" ${ }^{" 62}$. Suetónio não tem por Galba a simpatia que Tácito demonstra, seduzido pela sua austeridade e culto dos bons costumes. O retrato suetoniano está em consonância com a reputação que Galba adquire depois de aceder ao império: "Gozou de maior apoio e prestígio ao assumir o império do que ao governá-lo. Embora desse muitas provas dignas de um príncipe distinto, todavia de modo nenhum tão gratificantes como odiadas se tornaram as más acções" ${ }^{\text {"63 }}$. Mas das boas acções de governo não se fala. Já o precedia a fama de crueldade e avareza ${ }^{64}$.

À decrepitude física corresponde a senilidade, sugerida pela total dependência de três ministros corruptos. Torna-se incoerente nas decisões e a antítese da tradicional imagem de sabedoria que se atribui a um ancião: "ora mais rígido e poupado, ora mais brando e pródigo do que era conveniente a um príncipe eleito e à sua

Galb. 20.2: ... et quoniam capillo arripere non poterat, in gremium abdidit, mox inserto per os pollice ad Othonem detulit.

61

Gal. 20.2: 'Galba, Cupido, fruaris aetate tua'.

Hist. 1.7.2: Ipsa aetas Galbae inrisui ac fastidio erat adsuetis iunentae Neronis et imperatores forma ac decore corporis, ut est mos uolgi, comparantibus.

Gal. 14.1: Maiore adeo fauore et auctoritate adeptus est quam gessit imperium, quanquam multa documenta egregii principis daret; sed nequaquam tam grata erant, quam inuisa quae secus fierent. Cf. Tácito, Hist. 1.7.2. A ideia de que era um bom cidadão privado e um mau imperador também vem expressa em Tácito, Hist. 49: et omnium consensu capax imperii, nisi imperasset.

Gal. 12.1: Praecesserat de eo fama saeuitiae simul atque auaritiae. 
idade" ${ }^{\text {65 }}$. Mas para o biógrafo, Galba parece já não ter uma noção correcta do problema: o motivo que o leva a adoptar Pisão é estar convencido de que não era tanto a velhice que era objecto de desprezo, mas o facto de não ter filhos ${ }^{66}$.

A gota nas mãos (articularis morbus) poderá associar-se, como faz Marcial ${ }^{67}$, à ideia de avareza, característica de Galba. Com efeito, Suetónio apresenta-nos o retrato de um avaro, ilustrado com anedotas verdadeiras ou falsas, como ele próprio diz: Galba deplorou com gemidos um jantar, por ser mais requintado; ofereceu um prato de legumes a um administrador, como recompensa pelo seu bom trabalho; deu, do seu bolso, ao famoso flautista Cano a mísera gorjeta de cinco denários ${ }^{68}$. É a avareza que precipita o seu fim: ao adoptar Pisão, não concedeu às tropas o habitual donativo - facto que, como nota o biógrafo, favoreceu Otão (17), que se mostrava muito mais generoso para os soldados.

A descrição física de Vitélio aparece muito oportunamente inserida na narrativa da morte do imperador — um linchamento popular —, no momento em que se afirma que, além de lhe chamarem incendiário e alarve, havia quem lhe censurasse os defeitos do corpo. Diz o biógrafo que Vitélio "era de uma corpulência desmesura$\mathrm{da}$, tinha a face geralmente avermelhada pela embriaguez, o ventre obeso, uma coxa um pouco fraca, devido ao choque de uma quadriga, quando outrora prestava assistência a Gaio, que actuava como auriga" ${ }^{\text {69 }}$.

É um retrato muito negativo, em que os vícios corporais denunciam os vícios morais: a imagem apresentada ao longo da biografia é a de um glutão e de um ébrio.

Gal. 14.2: modo acerbior parciorque, modo remissior ac neglegentior quam conueniret principi electo atque illud aetatis. Cf. Tácito, Hist. 1.13. Cf. Martin R. 1991, Les douze Césars: du mythe à la réalité, 286-287.

67 Marcial, 1.98: Litigat et podagra Diodorus, Flacce, laborat. / Sed nil patrono porrigit: haec cheragra est.

68 Gal. 12.3. Para Plutarco, Gal. 16, a recompensa a Cano insere-se numa política de contenção contraposta à prodigalidade de Nero. Precisa que as moedas oferecidas são de ouro e acrescenta a afirmação de Galba de que o donativo não era retirado dos cofres do estado. Cf. Murison, Ch. L 1992, Suetonius Galba, Otho, Vitellius, ed. with introduction and notes by - , London, Bristol Classical Press, 65. Também Tácito, Hist. 1.49, dá uma imagem positiva da avareza de Galba, num retrato de sabor salustiano: ...pecuniae alienae non adpetens, suae parcus, publicae auarus.

Vit. 17.2: Erat enim in eo enormis proceritas, facies rubida plerumque ex uinulentia, uenter obesus, alterum femur subdebile impulsu olim quadrigae, cum auriganti Gaio ministratorem exhiberet. 
Galba nomeia-o legado do exército da Germânia, porque quem só pensa em comer e beber não pode ser perigoso e, com a abundância da província, poderia encher a sua goela sem fundo (Vit. 7.1). Na viagem, para ostentar familiaridade com os acompanhantes, mostra, com um arroto, que já almoçou (7.3). Quando se torna imperador, os seus banquetes são uma caricatura dos de Nero. As refeições multiplicam-se ao longo do dia. Tinha capacidade para tal quantidade de comida graças ao seu costume de vomitar. O irmão ofereceu-lhe um banquete onde entraram dois mil peixes de eleição e sete mil aves, mas Vitélio superou-o com um prato a que chamou "escudo de Minerva protectora da cidade". O biógrafo remata dizendo que era "homem não só de uma gula sem fundo, mas também sem hora e abjecta",70, pois durante os sacrifícios retira as vísceras e os bolos sagrados do fogo e come-os diante dos altares; e, durante as viagens, não se importa que a comida esteja ainda fumegante ou sejam restos da véspera. No final da vida, perante a aproximação do inimigo, foge para o Aventino, e os seus acompanhantes são apenas um padeiro e um cozinheiro (16.1).

A gula aparece ainda associada à crueldade atroz: manda reconduzir um condenado à sua presença e, quando todos celebravam já a clemência do imperador, este mandou executá-lo à sua frente dizendo que "queria dar alimento aos olhos",71.

Vitélio, além de glutão e ébrio, é ímpio: bebe - e, para mais, merum - para disfarçar o odor dos cadáveres, ao visitar o campo de batalha de Betríaco ${ }^{72}$. Na guerra com os partidários de Vespasiano, contempla, no meio de um banquete, o incêndio do Capitólio, cuja responsabilidade Suetónio, ao contrário de Tácito, atribui a Vitélio ${ }^{73}$. Parece ser alvo do ódio dos deuses, do princípio ao fim da Vida: o seu horóscopo é tão terrível que o pai em vida se opõe a que lhe atribuam uma província; e a mãe, ao saber que ele fora enviado para as legiões e proclamado imperador, chora-o como perdido (3.1). A Vida encerra-se com a interpretação de um presságio que, pela sucessão dos acontecimentos, se verifica que anunciava a sua morte.

Como o retrato físico, toda a vida de Vitélio é indigna: está associado aos piores vícios dos últimos Júlio-Cláudios. A meninice e a primeira adolescência passara-a

70 Vit. 13.3: homo non profundae modo, sed intempestiuae quoque ac sordidae gula ... Cf. Martin R. 1991, Les douze Césars: du mythe à la réalité, 115.

71 Vit. 14.2: 'uelle se' dicens 'pascere oculos'.

Vit. 10.3. Este é dos vários gestos referidos por Suetónio e que não figuram na descrição da mesma cena em Tácito, Hist. 2.70.

73

Vit. 15.3. Cf. sucessão dos acontecimentos relacionados com o incêndio em Tácito, Hist. 3.69-71. 
entre os prostitutos de Tibério em Cápreas: corria mesmo o boato de que o pai teria subido na carreira corporis gratia do filho ${ }^{74}$. E o biógrafo acrescenta que "também na seguinte idade foi conspurcado por todo o género de infâmias" $"$. Consegue o favor de Gaio pela comum paixão pelas corridas do circo, que lhe haviam de valer, como vimos, uma perna aleijada; o favor de Cláudio pela paixão pelo jogo dos dados; o favor de Nero pelas mesmas paixões e porque, ao presidir aos jogos Neronianos, juntara os seus rogos aos do povo para que o imperador participasse no concurso dos citaredos, o que Nero desejava, mas se não atrevia a fazer. De facto, este imperador toma Nero como modelo: presta um sacrifício aos manes do último dos JúlioCláudios; pede a um citaredo que cante uma composição da autoria dele num banquete solene (11.2) e governa o império segundo o arbítrio de histriões e aurigas (12).

$\grave{A}$ indignidade na vida corresponde a indignidade na morte. A narrativa da execução humilhante, interrompida pela inserção do retrato, é rematada de forma atroz: foi esquartejado, como um criminoso, junto às Gemónias, e arrastado com um gancho para o Tibre ${ }^{76}$. Este é o imperador mais odioso das Vidas. Suetónio não lhe perdoou ter sido o responsável pela morte de Otão.

Embora Domiciano seja apresentado como um terrível tirano, o seu retrato não é tão negro como o de Vitélio e apresenta aspectos bastante positivos ${ }^{77}$ :

tinha estatura elevada, o rosto modesto e muito ruborizado, olhos grandes, mas a vista bastante fraca; além do mais, era bem parecido e harmonioso, sobretudo na juventude, em todo o corpo, à excepção dos pés, onde os dedos eram demasiado curtos. Mais tarde, desfiguraram-no a calvície, o ventre obeso e as pernas

74 Vit. 3.2. Esta informação é suspeita, como todos os rumores sobre a devassidão de Tibério em Cápreas. Se Vitélio nasceu em 12 d. C. já tinha dezanove anos em 31, ano a partir do qual datam as histórias escabrosas sobre Tibério ${ }_{2} \mathrm{o}$ que se não conforma com pueritiam primamque adulescentiam Capreis egit, cf. Murison, Ch. L 1992, Suetonius Galba, Otho, Vitellius, 142.

Vit. 4: sequenti quoque aetate omnibus probris contaminatus.

Vit. 12.2. Tácito (Hist. 3.85) concede-lhe alguma dignidade no momento da morte: aos insultos de um tribuno, Vitélio responde que, apesar de tudo, fora imperator dele (cf. Díon Cássio, 65.21.2). E o historiador não deixa de censurar a vileza da multidão: Et uolgus eadem prauitate insectabatur interfectum qua fouerat uiuentem. Cf. Martin R. 1991, Les douze Césars: du mythe à la réalité, 380-385.

77 Dom. 18.1-8: Statura fuit procera, uultu modesto ruborisque pleno, grandibus oculis, uerum acie hebetiore; praeterea pulcher ac decens, maxime in iuuenta, et quidem toto corpore exceptis pedibus, quorum digitos restrictiores habebat; postea caluitio quoque deformis et obesitate uentris et crurum gracilitate, quae tamen ei ualitudine longa 
delgadas, que emagreceram ainda mais, devido a uma longa doença. Confiava tanto no aspecto tímido do rosto, que um dia disse no senado: 'até aqui, não há dúvida, aprovastes não só o meu carácter, como também a minha face'. Desgostava-o tanto a calvície, que tomava mesmo como ofensa pessoal, se se apontava a outro este defeito numa brincadeira ou numa altercação.

Embora sejam visíveis certos traços comuns ao pai e ao irmão - a beleza de Tito e a tendência para a obesidade, bem como a calvície de Vespasiano - , sugerese uma degeneração. A gracilitas crurum, comum aos príncipes que levam um regime de vida decadente (Calígula e Nero) ${ }^{78}$, associada ao ventre obeso (que partilha com Nero e Vitélio), são traços congruentes com a vida sedentária de Domiciano: inimigo da fadiga, não andava a pé nem a cavalo (19) ${ }^{79}$. A calvície despertaria comentários - Juvenal (4.38) chama-lhe Nero Calvo. Domiciano escreve mesmo um livro de cura capillorum (18.2).

É provável que Suetónio ${ }^{80}$ queira sugerir, com a decadência física, a degradação moral: "Quanto à administração do império, mostrou-se durante algum tempo variável, misturando mesmo de forma equilibrada vícios e virtudes, até que transformou também as virtudes em vícios: quanto se pode conjecturar, além das tendências naturais, a carência tornou-o rapace e o medo, cruel"81.

As afirmações sobre a forma como usava a aparência modesta do rosto ruborizado, sugerem a sua capacidade de dissimulação, comum a outros maus príncipes, como Tibério, Calígula e Nero. Já durante a guerra com Vitélio, a forma como escapa do Capitólio, disfarçado de sacerdote de Ísis (1.2), revela os seus dotes. Diz o biógrafo que Domiciano simulou admiravelmente modéstia e dedicação à poesia (2.2). Tal propensão levanta suspeitas sobre o horror que manifestava, no início, por todo o

remacruerant. Commendari se uerecundia oris adeo sentiebat, ut apud senatum sic quondam iactauerit: 'usque adhoc certe et animum meum probastis et unltum'. Caluitio ita offendebatur, ut in contumeliam suam traheret, si cui alii ioco uel iurgio obiectaretur. Couissin, J. 1953, "Suétone physiognomoniste", 252, sugere que restrictiores se deve traduzir antes por 'recurvados', como garras, traço que, segundo as teorias fisiognomonistas, seria sinal da rapacitas característica de Domiciano. Gascou, J. 1984, Suétone historien, 613, n. 598, contesta a intenção fisiognomónica de Suetónio e a interpretação sugerida para a palavra.

Stok, F. 1995, "Ritratti fisiognomici in Suetonio", 127.

79 Ora esta debilidade física combatia-a Germânico com frequentes exercícios de equitação, cf. Cal. 3.1. Cf. Stok, F. 1995, "Ritratti fisiognomici in Suetonio", 127.

80 Como sugere Stok, F. 1995, "Ritratti fisiognomici in Suetonio", 130-131.

81

Dom. 3.2; Cf. 9.1; 10.1 . 
género de morte e da liberalidade que demonstrava (9.1). O facto de mandar abandonar Tito enfermo como se estivesse morto (2.3), e de, no início do reinado, passar horas fechado a espetar moscas com um estilete (3.1) já denunciava a sua misantropia e crueldade. Em breve descamba claramente para a saeuitia e para a cupiditas (10). É significativo que as únicas obras que leia sejam os commentarii e os acta de Tibério (20). À medida que o carácter vai sendo revelado, o leitor fica a saber que, já desde a juventude, não tinha nada de afável, era insolente e sem mesura nas palavras e nas obras $^{82}$. A arrogância leva-o ao ponto de se proclamar, no começo de uma carta, dominus et deus (13.2). Torna-se objecto do terror e do ódio de todos e, por conseguinte, é morto $^{83}$. Os soldados lamentam a morte e querem divinizá-lo (23.1), mas é o senado quem escreve a história. Se a tradição sobre Domiciano tivesse origem em fontes militares, a reputação do imperador seria certamente mais positiva.

\section{Dois histriões tirânicos: Calígula e Nero}

Suetónio divide a biografia de Calígula entre actos de princeps e actos de monstrum, mas o retrato físico que apresenta inclui-se na segunda categoria:

Era de estatura elevada, tez muito pálida, corpo desproporcionado, o pescoço e as pernas extremamente delgados, os olhos e as têmporas encovados, uma fronte vasta e sanhuda, o cabelo ralo e nenhum no alto da cabeça, o resto do corpo hirsuto, pelo que era considerado crime, e de morte, olhar de cima, à passagem dele, ou sequer pronunciar a palavra "cabra" 84 a qualquer pretexto. Quanto ao rosto, medonho e repugnante por natureza, tornava-o de propósito ainda mais feroz, trabalhando-o ao espelho para assumir todas as expressões aterradoras e espaventosas ${ }^{85}$.

Dom. 12.3: Ab iuuenta minime ciuilis animi, confidens etiam et cum uerbis tum rebus immodicus.

Dom. 14.1: Per haec terribilis cunctis et inuisus, tandem oppressus est.

84 A ideia de Couissin, J. 1953, "Suétone physiognomoniste", 247-248, de que Calígula faz aqui alusão à fisiognomonia zoológica, é contestada por Gascou, J. 1984, Suétone historien, 609-610. Para este autor, a analogia é apenas impressionista e resulta dos traços físicos indicados.

Cal. 50.1: Statura fuit eminenti, colore expallido, corpore enormi, gracilitate maxima ceruicis et crurum, oculis et temporibus concauis, fronte lata et torua, capillo raro at circa uerticem nullo, hirsutus cetera. Quare transeunte eo prospicere ex superiore parte aut omnino quacumque de causa capram nominare criminosum et exitiale habebatur. Vultum uero natura horridum ac taetrum etiam ex industria efferabat componens ad speculum in omnem terrorem ac formidinem. Suetónio mostra-se dependente de uma tradição literária. No extremo oposto, a iconografia apresenta Calígula como o mais belo dos príncipes: mas deve-se ter em conta a idealização. Cf. Gascou, J. 1984, Suétone historien, 614, n. 602. 
Tal descrição do monstro, como sugere o desequilíbrio entre corpus enorme e pescoço e as pernas delgadas, contrasta com o retrato físico e moral do pai de Calígula, Germânico, apresentado no início da biografia ${ }^{86}$. Quase todos os imperadores eram bons antes de serem imperadores e a morte prematura deste popular general favoreceu a idealização da imagem. Em comum com o pai, tem Calígula a magreza das pernas. Mas o biógrafo diz-nos que Germânico corrigiu este defeito com o hábito da equitação.

A imagem visual de Calígula torna-se consonante com o seu carácter. Desde cedo Calígula se mostra incapaz de dominar a natura saeua atque probrosa (11). Já Tibério percebera que Gaio vivia para a sua perdição e a de todos: que era uma Hidra para o povo romano e um Faetonte para o orbe (11). É a natura saeua que o leva a assistir cupidissime aos suplícios dos condenados (11). Mas, na parte relativa à descrição do monstrum (22.1 ss), Suetónio fala de saeuitia ingenii: uma frase que gosta de repetir é "odeiem-me, desde que me temam!"87. Àqueles que, por ocasião de uma grave doença do imperador (que então gozava das boas graças de todos), fizeram votos de lutar na arena ou morrer pelo seu restabelecimento, Calígula exige o cumprimento desses votos (27.2); obriga os pais a assistirem à morte dos filhos e corta a língua a um cavaleiro para não proclamar a sua inocência (27.4); suscita o linchamento de um senador pelos seus pares e só se dá por satisfeito ao ver, dispostos aos seus pés, os membros e as entranhas do infeliz (28); lamenta o facto de sob o seu governo não acontecerem catástrofes (31); gosta de assistir à decapitação de condenados durante os banquetes e manda precipitar no mar a multidão que assistia ao cortejo espectacular da ponte de Baias ${ }^{88}$. Aos actos

Cal. 3.1: Omnes Germanico corporis animique uirtutes, et quantas nemini cuiquam, contigisse satis constat: formam et fortitudinem egregiam.... Formae minus congruebat gracilitas crurum, sed ea quoque paulatim repleta assidua equi uectatione post cibum. Os estudos sobre as teorias fisiognomonistas, a partir do retrato de Calígula, indicam um carácter libidinoso, despudorado, louco, criminoso e pérfido. Cf. Couissin, J. 1953, "Suétone physiognomoniste", 249-251. Este autor acha que o retrato foi composto ou ajustado para confirmar o carácter de Calígula. Gascou, J. 1984, Suétone historien, 607610 , admite que o retrato de Calígula seja o que mais se conforma à teoria de Couissin, embora note que a coerência não é perfeita.

Cal. 30.1: oderint, dum metuant. Cf. Tib 59.2: oderint, dum probent.

Cal. 32.1; cf.Cal. 19. Veyne, P. 1983, "Le folklore à Rome et les droits de la conscience publique sur la conduite individuelle": Latomus 42 18-25, considera que a loucura de Calígula se manifesta em restaurar tradições de um passado rude. Calígula era um folclorista. Em uma festa colectiva e em uma inauguração impunham-se sacrifícios e vítimas. Antonelli, G. 2001, Caligola. Imperatore folle o principe inadeguato al ruolo 
cruéis junta o humor negro. Certo dia, durante um banquete, aos cônsules que lhe perguntavam educadamente de que estava a rir, responde: "De que há-de ser, disse ele, senão de que me bastaria um só aceno para vos fazer degolar aos dois imediatamente?"89. E, sempre que beijava o pescoço da mulher ou da amante: "Tão bela cerviz tombará, mal eu o ordenar" ${ }^{\prime \prime 0}$. E repetia que era capaz de recorrer à tortura para saber porque é que amava tanto Cesónia.

A crueldade é agravada pela inveja: mandou matar o seu parente Ptolomeu da Mauritânia, porque o fulgor da púrpura do seu manto tinha atraído todos os olhares durante um espectáculo ${ }^{91}$; e Colósseros, pela imponência e beleza que lhe valeram tal nome ${ }^{92}$.

A natura probrosa é manifesta inicialmente nas deambulações nocturnas por tabernas e bordéis e na forma empenhada como se entregava às artes cénicas do canto e da dança, desmandos que Tibério tolerava na esperança de que lhe amenizassem a índole feroz (11). Acresce o incesto com todas as irmãs, particularmente com Drusila, a quem violentara na juventude e por quem nutria uma louca paixão (24.1). Prostitui as restantes aos seus favoritos (24.3). Mantém comércio car-

assegnatogli dalla sorte?, I volti della storia 92, Roma, Newton \& Compton, 124, pensa que seriam apenas brincadeiras de hóspedes mais atrevidos e os afogamentos seriam exagero dos autores antigos.

Cal. 32.3: 'Quid', inquit, 'nisi uno meo nutu iugulari utrumque uestrum statim posse?' Anedota não atestada em outra fonte.

90 Cal. 33: 'Tam bona ceruix simul ac iussero demetur.' Referir que o dizia 'sempre' (quotiens), em relação ao pescoço das esposas e amantes, parece exagero de Suetónio, na mira de apresentar um imperador obcecado pela ideia da decapitação; cf. 30.2: 'Vtinam p. R. unam ceruicem haberet!' Neste passo se inspira Camus para a cena do estrangulamento de Cesónia.

Cal. 35.1. Esta morte levanta questões políticas que Suetónio não indica. Faur, J.-C. 1973, "Caligula et la Maurétanie: la fin de Ptolémée": Klio 55 248-271, apresenta como motivo da morte o envolvimento na conjura de Getúlico; a descendência de Marco António tornava Ptolomeu um potencial rival de Calígula. Gascou, J. 1984, Suétone historien, $420 \mathrm{n} .152$, considera inverosímil, e de modo algum sugerido por Suetónio, que Ptolomeu fosse um potencial rival de Calígula. Para Barrett, A. A. 1989, Caligula. The corruption of power, London / New York, Routledge, 116-118, e Antonelli, G. 2001, Caligola, 140-142, dado o contexto em que ocorreu a morte de Ptolomeu, este deve terse envolvido numa conjura, seduzido talvez pela promessa de um reino independente.

Cal. 35.2. O ritual que envolve esta morte, bem como a do homem que oferecera a vida pelo restabelecimento do imperador (27.2), assemelha-se ao de uma vítima a caminho do sacrifício. Tratar-se-ia de um antigo ritual de justiça colectiva, restaurado devido ao gosto folclorista de Calígula; cf. Veyne, P. 1983, "Le folklore à Rome", 18-25. 
nal com o pantomimo Mnester e com o jovem Valério Catulo (36.1); avalia as mulheres mercantium more à frente dos maridos, arrebata-as do triclínio e, de regresso ao lugar, comenta o corpo de cada uma e a performance na cama ${ }^{93}$.

$\mathrm{O}$ facto de assumir vários aspectos frente ao espelho, pormenor que Camus explora repetidamente no seu Caligula, remete para o carácter histriónico do imperador. Já durante a parte favorável do reinado, em que Suetónio fala quasi de principe, se nota a exibição teatral da pietas : faz o elogio fúnebre de Tibério, com grande efusão de lágrimas; procede à transladação das cinzas da mãe e do irmão, mesmo com mau tempo, "para que mais sobressaísse a sua devoção"; e a deposição no mausoléu efectua-se nec minore scaena (15). Como novo e inaudito espectáculo é apresentada a ponte entre Baias e Putéolos, que o imperador atravessa em trajes triunfais (19); e com um mimus é conotado um exercício da campanha militar na Germânia, toda ela farsesca (45.1-2). Além disso, faz cavalgar Cesónia ao seu lado, ornada de clâmide, escudo e elmo (25.3). Imita a voz do actor trágico e o gesto do histrião. Tinha planeado a sua estreia em cena para a noite do dia em que foi assassinado; e, certa vez, convocara a meio da noite os aterrorizados senadores e aparecera-lhes em trajes de cena a dançar uma pantomima (54).

O seu carácter histriónico é reforçado pela indumentária, classificada numa sugestiva gradação: "Nas roupas e no calçado e no restante trajar não usou o tradicional do seu país, nem o habitual dos cidadãos, nem sequer masculino e, em suma, nem humano" 94 . Parece ficar sugerido que, na sua loucura, Calígula não conseguia separar a licentia de cena da realidade. Na lista de roupas e adereços apresentados, encontramos roupas efeminadas (manulatus et armilatus; sericatus et cycladatus); roupas e calçado oriental (crepidae) ${ }^{95}$; calçado dos reis helenísticos e do actor trágico (coturni); calçado dos correios militares e talvez de Hércules (speculatoria caliga); calçado de mulher e dos actores cómicos (soccus mulieris); atributos divinos:

93 Cal. 36.2. Augusto, apesar de ter um comportamento muito semelhante, não é tão censurado, cf. Aug. 69.1. Com as notícias eróticas, Suetónio procura demonstrar que Calígula viola todas as normas sexuais através da homossexualidade, incesto, adultérios e travestismo. O relacionamento sexual prova a monstrositas, cf. Wardle, D. 1994, Suetonius' Life of Caligula. A commentary, Bruxelles, Latomus, 275; Martin, R. 1991, Les douze Césars, cit.,157-158.

94

Cal. 52: Vestitu calciatuque et cetero habitu neque patrio neque ciuili, ac ne uirili quidem ac denique humano semper usus est.

95

O tipo de calçado que Tibério usava em Rodes; Tib 13.1: redegitque se deposito patrio habitu ad pallium et crepidas. 
barba de ouro, raio, tridente, caduceu ${ }^{96}$. Travestia-se mesmo de Vénus; usava roupas triunfais e até a couraça de Alexandre Magno ${ }^{97}$.

Calígula comportava-se como um deus. Consagrou um templo ao seu numen, com sacerdotes e vítimas e uma estátua de ouro que todos os dias era vestida com roupa igual à do imperador ${ }^{98}$; em noites de lua-cheia, convidava a Lua a vir dormir com ele ${ }^{99}$; chegava mesmo a conversar com Júpiter e a ameaçá-lo —-"ou tu dás cabo de mim ou eu de ti!" - ou a dizer que o deus o convidava para o seu contubernium ${ }^{100}$.

Favorece ad insaniam os que caem nas suas graças: o pantomimo Mnester; os gladiadores trácios; os aurigas da facção dos verdes e o seu cavalo Incitatus que, segundo o rumor, queria fazer cônsul (55). De facto Suetónio deixa claro que "nem

97 Por Díon Cássio, 59.17.3, sabemos que usou a couraça de Alexandre na travessia da ponte de Baias. Cf. os comentários de Wardle, D. 1994, Suetonius' Life of Caligula, 336341; Hurley, D. W. 1993, An historical and historiographical commentary on Suetonius' Life of C. Caligula, Atlanta, Scholars Pr., 186-189; Guastella, G. 1992, Gaio Svetonio Tranquillo, La vita di Caligola, [testo, trad. e commento] a cura di -, Roma, La Nuova Italia Scientifica, 272-273.

98 Cal. 22.2-3. Honras já oferecidas aos antecessores, mas que estes tinham recusado; cf. Aug. 52 e Tib. 26.1. Cf. Camus, Caligula III, 2: On ne comprend pas le destin et c'est pourquoi je me suis fait destin. J'ai pris le visage bête et incompréhensible des dieux. C'est cela que tes compagnons de toute à l'heure ont appris à adorer.

Cal. 22.4. Camus encarece e repete este motivo, dando-lhe o valor simbólico do impossível a que Calígula aspira. Cf. Strauss, W. A. 1951, “Albert Camus' Caligula. Ancient sources and modern paralels": CompLit 3 160-173, para o caso, 165; Gillis, J. 1974, "Caligula. De Suétone à Camus": LEC 42 393-403, especialmente, 401. Cf. tentativas de explicação resumidas em Wardle, D. 1994, Suetonius' Life of Caligula, 214-215. Talvez se trate de um rito (mal interpretado por fontes hostis) ligado ao culto de Ísis; $\mathrm{cf}$. Ceausescu, P. 1973, “Caligula et le legs d'Auguste”: Historia 22, 277. Como Ísis aparece associada à lua em Apuleio, Met. 11.3-6, Calígula, nas suas aspirações a uma monarquia de tipo egípcio, poderia muito bem estar a identificar-se com Osíris. Ora, segundo Martin R. 1991, Les douze Césars: du mythe à la réalité, 331-332, embora não sejam de excluir traços de demência, a que os autores antigos atribuem a busca de uma divinização, importa ter presente a ideologia geral do reino - uma monarquia teocrática, fundamentada na osmose entre um princípio de consecratio à maneira do monarca egípcio e o culto clássico dos deuses romanos.

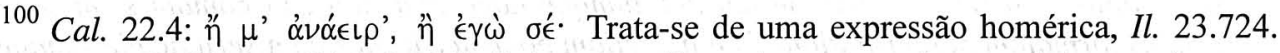
Segundo Séneca, Dial. 3.20.8, Gaio respondia assim aos trovões que interrompiam um espectáculo de um pantomimo durante um banquete. Cf. Díon Cássio, 59.28.6. 
tinha firme a saúde do corpo nem a da alma"101, e que o próprio tinha consciência da sua perturbação mental ${ }^{102}$; um desequilíbrio que o biógrafo atribui expressamente à coexistência de dois vícios opostos: extrema confiança e excessivo medo (51.1). A vida parece decorrer numa espécie de delírio báquico que precipita a morte, num momento em que projectava crimes ainda maiores (49.2): "perante tal delírio báquico e tal devastação não faltou a muitos a coragem de o atacar"103.

O retrato de Nero não apresenta uma continuidade tão visível com a vida, mas não deixa de haver correspondências:

Tinha uma estatura quase mediana, o corpo com manchas e malcheiroso, o cabelo alourado, o rosto belo, mais que sedutor, os olhos esverdeados e muito fracos, o pescoço obeso, a barriga proeminente, as pernas muito delgadas... Em relação aos cuidados corporais e vestuário, apresentava-se tão indecente que trazia a cabeleira sempre penteada em degraus e, na viagem à Acaia, mesmo caída sobre a nuca, e geralmente apresentava-se de roupão em público, com um lenço atado à volta do pescoço, sem cinto e descalço ${ }^{104}$.

${ }^{101}$ Cal. 50.2: Valitudo ei neque corporis neque animi constitit.

${ }^{102}$ Cal. 50.2. Várias são as tentativas modernas para explicar a doença. Lucas, J. 1967, "Un empereur psychopathe. Contribution à la psychologie du Caligula de Suétone": AC 36 159189 , propõe psicopatia resultante do corte entre o nível mental e o afectivo. Katz, R. S. 1972, "The illness of Caligula": CW 65 223-225, propõe hipertiroidismo, na sequência de um colapso nervoso, mas é contestado por Morgan, M. G. 1973, "Caligula's illness again": CW 66 327-329, e por Massaro, V. \& Montgomery, I. 1978, "Gaius — mad, bad, ill, or all three?": Latomus 37 894-909, e idem 1979, "Gaius (Caligula) doth murder sleep": Latomus 38 699-700, que, por sua vez propõem mania. Benediktson, D. Th. 1988-1989, "Caligula's madness. Madness or interictal temporal lobe epilepsy?" CW 82 370-375, baseando-se em estudos sobre comportamentos de doentes por comparação com o de Calígula, aponta, como se vê pelo título do seu estudo, um tipo específico de epilepsia. Segundo este autor, o boato do filtro de Cesónia poderia ter provindo da boca do próprio Calígula, consciente de que tinha problemas psíquicos. $\mathrm{O}$ facto de dizer que seria capaz que recorrer à tortura para saber a razão por que a amava tanto (33), significava que ele pensava verificar, por esse meio, se ela lhe tinha dado, de facto, qualquer afrodisíaco.

${ }^{103}$ Cal. 56.1: Ita bacchantem atque grassantem non defuit plerisque animus adoriri.

${ }^{104}$ Nero 51: Statura fuit prope iusta, corpore maculoso et fetido, subflauo capillo, uultu pulchro magis quam uenusto, oculis caesis et hebetioribus, ceruice obesa, uentre proiecto, gracillimis cruribus... Circa cultum habitumque adeo pudendus, ut comam semper in gradus formatam peregrinatione Achaica etiam pone uerticem summiserit ac plerumque synthesinam indutus ligato circum collum sudario prodierit in publicum sine cinctu et discalciatus. 
Nota-se um misto de beleza e fealdade, que pode corresponder à divisão que Suetónio opera na biografia entre acções boas e acções más (19.3). O pescoço e o ventre reflectem os excessos da mesa (27.2). Desde o início da biografia que é acentuada a ligação aos Domícios, de quem, diz o biógrafo, Nero degenerou as virtudes e repetiu os defeitos ${ }^{105}$. O lendário cognome de Enobarbo (1.1) é ligado a características morais pelas espirituosas palavras de Licínio Crasso: «não é de admirar que tenha uma barba de bronze quem tem uma cara de ferro, um coração de chumbo» ${ }^{106}$. A reputação dos Domícios é de homens detestáveis. O próprio pai de Nero admite que dele e de Agripina não podia nascer senão algo detestável e mau para os cidadãos (6.1).

O corpo manchado e fétido recorda as manchas morais resumidas nos probra e nos scelera (19.39), mas o aspecto negativo recai sobretudo na forma de Nero se apresentar, onde há claramente um juízo moral (adeo pudendus). Nos probra se incluem as suas tendências histriónicas, evocadas nas roupas, e o gosto pela arte do auriga, de que poderá ser sinal o estilo do cabelo ${ }^{107}$. O gosto pelo teatro, que já se adivinhava, na parte positiva da biografia, pela ostentatio de virtudes (9-10) e na recepção a Tiridates da Arménia, explicitamente inserida inter spectacula ab eo edicta (13.1-2), realiza-se no aparecimento de Nero em cena, a cantar e a tocar cítara, primeiro em Nápoles, em ambiente grego (20.1), a seguir na Urbe, o que era uma infâmia (22), e depois no orbe, numa digressão pela Grécia (22.3). O triunfo organizado pelo seu regresso é o do actor (25.1-2).

Aos probra sucedem-se os scelera, que parecem consequência do facto de o imperador se tornar actor. Para a mentalidade romana, tal comportamento constituía não só degradação social, mas também moral. E a Vida de Nero sugere uma implícita osmose entre o teatro e a vida. Aos papéis interpretados por Nero - Cánace em trabalho de parto, Orestes matricida, Édipo cego, Hércules furioso - podem asso-

105 Nero 1.2: Pluris e familia cognosci referre arbitror, quo facilius appareat ita degenerasse a suorum uirtutibus Nero, ut tamen uitia cuiusque quasi tradita et ingenita ret $<t>$ ulerit.

${ }^{106}$ Nero 2.2: 'non esse mirandum, quod aeneam barbam haberet, cui os ferreum, cor plumbeum esset'.

${ }^{107}$ Cf. Bradley, K. R. 1978, Suetonius' Life of Nero. An historical commentary, Bruxelles, Latomus, 284-285: o estilo do cabelo assemelha-se ao de um busto de auriga contemporâneo de Nero - daí que fosse tão escandaloso para um romano. Outra explicação é que seria influência de um penteado usado por Alexandre Magno e assim um sintoma da influência do helenismo no principado de Nero. 
ciar-se comportamentos reais deste imperador ${ }^{108}$. As máscaras de heróis e deuses, de heroínas e deusas têm os traços dele próprio ou de mulheres que gozam do seu favor (21.3). Deseja o incesto com a mãe ${ }^{109}$, recebe Esporo como esposa, com dote, véu e cortejo nupcial ${ }^{110}$, e Doríforo como esposo, até ao ponto de imitar as virgens a serem violentadas ${ }^{111}$. O parricídio começa no pai adoptivo, Cláudio (33), e termina na pátria (38). Depois da dolosa morte da mãe (34.2-3), torna-se um perseguido

108 Nero 21.3. Cada um destes papéis é uma máscara do próprio Nero, desflorado por Doríforo (29), incestuoso (28.2), assassino da mãe (34.1-4), assassino de amigos e esposas (35.2-3, 5), conforme sugere Lounsbury, R. C.1991, "Inter quos et Sporus erat: The making of Suetonius' Nero": ANRW II, 33,5, Sprache und Literatur, 3775; cf. Martin R. 1991, Les douze Césars: du mythe à la réalité, 264.

Nero 28.2. A prova apresentada por Suetónio, e da qual qual nemo dubitauit, é que tinha como concubina uma meretriz parecida com Agripina. O biógrafo acrescenta o boato de que, depois de passear com Agripina na liteira, Nero apresentava manchas suspeitas na roupa. Cf. Lounsbury, R. C.1991, "Inter quos et Sporus erat", 59. Tácito, Ann. 14.12.1, rejeita a versão de Fábio Rústico, seguida por Suetónio, e segue a versão de Clúvio Rufo, que atribui a iniciativa a Agripina, para assegurar o favor do filho. E Séneca procurou contrapor Acte aos intentos da Augusta. O incesto não passaria de um rumor, cf. Verdière, R. 1975, “À verser au dossier sexuel de Néron”: PP 30 5-22; Martin R. 1991, Les douze Césars: du mythe à la réalité, 145; Baldwin, B. 1983, Suetonius, 178. Gascou, J. 1984, Suétone historien, 441-442 n. 207, lança a hipótese de o rumor ter surgido de uma graça de mau gosto de Nero: a semelhança da meretriz com Agripina tê-lo-ia levado a dizer que tinha comércio com a mãe.

${ }^{110}$ Nero 28.1. Ritual que tem sido visto como uma cerimónia de iniciação numa religião mistérica: Esporo teria sido castrado, porque era servidor de Cíbele. O flammeum é também o véu do iniciado. Quanto à cerimónia do casamento, talvez se tratasse, de facto, de uma iniciação, em que Esporo, pela sua união matrimonial com Mitra, acedia ao título de nymphus, cf. Verdière, R. 1975, “À verser au dossier sexuel de Néron”, 21-22; Bradley, K. R. 1978, Suetonius' Life of Nero, 161-162; Cizek, E. 1982, Néron, Paris, Fayard, 41; Martin R. 1991, Les douze Césars: du mythe à la réalité, 171; Fernández Uriel P. 1994, "Tácito, Annales XV, 37,8 y Suetonio, Nero XXVIII y XXIX. ¿Interpretación sexual o religiosa?”: Sexo, muerte y religión en el mundo clásico, Alvar, J.; Blánquez, C.; Wagner, C.(eds.), Madrid, Ed. Clásicas, 111-124. V. n. seguinte.

111 Nero 29. É provável que este Doríforo e o Pitágoras mencionado por Tácito, Ann. 15.37.4, sejam a mesma pessoa. Como no caso de Esporo, poderia tratar-se de um casamento místico, no qual Nero seria o iniciado. Doríforo seria, não o nome próprio, mas a função que desempenhava como ministro do culto de Cíbele ou de Mâ-Belona, cf. Verdière, R. 1975, “À verser au dossier sexuel de Néron”, 19-20; Bradley, K. R. 1978, Suetonius' Life of Nero, 164-165; Cizek, E. 1982, Néron, 41-42; Martin R. 1991, Les douze Césars: du mythe à la réalité, 160 e 169-171; Fernández Uriel P. 1994, "Tácito, Annales XV, 37,8 y Suetonio, Nero XXVIII y XXIX.", 111-124. 
das Fúrias (34.4); e é no aniversário da morte de Agripina que receberá a notícia da revolta da Gália (40.4), que marca o princípio da sua própria tragédia. O leque das vítimas é vasto, mas no cúmulo dos crimes está o facto de não poupar nem os muros da pátria. Nero é apresentado como evidente culpado do incêndio de 64 (incendit urbem tam palam $)^{112}$. Mas, mais grave, é que nele encontra o cenário para cantar, em traje de cena, "a tomada de Ílion"113.

No relato da morte (42-49) as referências às actividades teatrais são uma constante e a morte de Nero é a tragédia de um actor que, querendo levar a arte à sua perfeição, entra em choque com a mentalidade romana e se vê forçado ao suicídio. Desejoso de fama eterna (55), procura fazer da sua morte um grande destino trágico e repete entre lágrimas: 'Qualis artifex pereo! ${ }^{114}$; Se foi muito odiado - a plebe festejou a sua morte envergando o pileus, barrete simbólico da libertação - também foi muito amado: colocavam-se flores no túmulo e, mesmo vinte anos mais tarde, um falso Nero foi acolhido com entusiasmo entre os Partos (57).

Destes retratos concluímos que não há um paradigma único. A relação entre a

112 Tácito, Ann. 15.38.1, apresenta duas versões que corriam sobre a causa do incêndio: o acaso ou o dolus principis. Os boatos sobre a culpa de Nero poderão ter surgido posteriormente, a partir do empenho que pôs na reconstrução e na qualidade dos edifícios. Nero parece ter sido a única pessoa a fazer esforços para o combate ao incêndio ou para reduzir os seus efeitos, como sublinha Holson, P. 1976, "Nero and the fire of Rome. Fact and fiction": Pegasus 19 37-44. Não se entende em que é que Nero beneficiaria com este incêndio: é pouco provável que quisesse destruir a Domus Transitoria, que estava em construção, cf. Bradley, K. R. 1978, Suetonius' Life of Nero, 231.

113 Nero 38.2: Hoc incendium e turre Maecenatiana prospectans laetusque 'flammae', ut aiebat, 'pulchritudine' Halosin Ilii in illo suo scaenico habitu decantauit. Suetónio apresenta como facto o que Tácito, Ann. 15.39, refere como rumor. Suetónio coloca a cena na torre de Mecenas (nos jardins do Esquilino), Tácito num palco particular e Díon Cássio, 62.18.1, no telhado do palácio. Ora os três locais mencionados parecem ter sido pasto das chamas, cf. Holson, P. 1976, "Nero and the fire of Rome. Fact and fiction", 43. Suetónio cede à versão mais romanesca: cf. Gascou, J. 1984, Suétone historien, 442-443.

114 Nero 49.1. Segundo Lorenzo, E. di 1981, ."A proposito dell'espressione neroniana qualis artifex pereo (Suet., Nero 49)": Studi salernitani in memoria di R. Cantarella, a cura di Gallo I., Univ. di Salerno (Ist. di Filol. Class), Laveglia, 523-535, artifex, dado o amplo campo semântico (nenhum outro termo para actor designava tão bem a polivalência de Nero) e o seu valor expressivo no contexto, rico de dramaticidade, em que foi pronunciado, é a palavra adequada: Nero queria recordar a si e aos outros não só que fora poeta, auriga, artista, mas sobretudo um actor completo, que na cena e na vida soubera recitar bem a sua parte. 
personalidade apresentada ao longo da biografia e o retrato físico não se estabelece sempre da mesma forma. Num extremo está Calígula, cujo retrato se conforma com o monstro louco, como é explicitamente apresentado, e no outro situa-se Otão, cuja debilidade física e modos, embora coerentes com a primeira parte da vida, contrastam, como nota o próprio biógrafo, com a virilidade demonstrada na morte, onde o verdadeiro carácter se revela. Os hábitos efeminados são partilhados também por César, mas neste atenuados pelo vigor e beleza física. Mais exagerados são o cultus e o habitus de Calígula e de Nero, cujo modo de vestir vai contra todas as convenções sociais romanas.

Está presente a ideia de que o equilíbrio psicofísico pressupõe um regime de vida moderado ${ }^{115}$. Destacam-se alguns traços comuns aos maus príncipes: o ventre obeso, evidente sinal de excessos, figura em Nero, em Vitélio, um pouco em Tito e em Domiciano, e a gracilitas crurum é comum a Calígula, em quem é extrema, Nero e Domiciano.

Certos dados são neutros: a força e o vigor do corpo podem ser usados para o bem ou para o mal. A harmonia dos membros parece sugerir o equilíbrio psicofísico de Augusto, Vespasiano e César; e que falta a Tibério, a Calígula e a Vitélio. A beleza tende a acentuar-se nos bons imperadores (Augusto, Vespasiano, Tito), embora seja referida nos maus (Nero, Domiciano). Os bons têm alguns traços negativos e os maus alguns traços positivos. Também do ponto de vista moral não há imperadores exclusivamente bons, nem exclusivamente maus.

O problema é complexo, como complexas são as pessoas. As sugestões, decorrentes da leitura dos retratos físicos, não esgotam a personalidade dos Césares. Apesar do esquematismo aparentemente repetitivo das Vidas, há diferenças de tratamento que individualizam cada imperador e tornam artificial e incompleta qualquer classificação tipológica. Mais do que um esquema preestabelecido, parecem ser os dados que o biógrafo possui e a arrumação que lhes dá a determinarem o número e as qualidades que determinam as species $^{116}$ : as qualidades do carácter de cada imperador são inferidas, por indução, a partir dos seus actos e palavras. Feito este trabalho prévio, o biógrafo, ao redigir cada Vida, enuncia, mais ou menos explicitamente, as qualidades, seguidas dos exemplos que as ilustram. Universais são as

${ }^{115}$ Stok, F. 1995, "Ritratti fisiognomici in Suetonio", 129.

${ }^{116}$ Cf. Aug. 9. Em cada Vida, há partes narradas cronologicamente (per tempora), sobretudo infância e juventude até à ascensão ao poder, e partes sistematizadas por rubricas (per species), que analisam vícios e virtudes e a vida pessoal. 
qualidades - os uitia e as virtutes de cada princeps -, os principes são individuais. Mas o carácter de cada imperador não pode ser determinado apenas pelo somatório dos vícios e virtudes. Cada princeps é individuado, sem dúvida, pelas virtudes e pelos vícios que apresenta, mas não menos pelo grau em que os apresenta e pela relação de forças entre vícios e virtudes. O grau das qualidades e a relação de forças entre elas são estabelecidos pelo número dos exempla, pelo seu peso, pela forma de os organizar dentro das species (em crescendo ou decrescendo; generalizando ou omitindo) e pela composição da biografia no seu todo: o biógrafo altera amiúde a cronologia; suspende ou antecipa informação; divide a biografia em actos louváveis e censuráveis ou simplesmente alterna aspectos positivos e negativos; insinua mudança abrupta ou sugere progressiva evolução no carácter; aduz opiniões de terceiros, de modo especial, as reacções à morte; recorre à deformação cómica ou à tensão trágica — gera, em suma, maior ou menor dramatismo, na procura de incutir determinado juízo no leitor. Neste sentido, o biógrafo parece situar-se algures entre o historiador e o dramaturgo.

Assim, além de esporádicos comentários do biógrafo, a conclusão a tirar sobre determinado César é, essencialmente, sugerida pela técnica biográfica. Nos imperadores bons há um processo evolutivo do negativo para o positivo (Augusto, Otão, Tito), a deixar uma impressão favorável ao leitor. Nos maus, observa-se a progressão contrária (Tibério e Galba), ou a apresentação em primeiro lugar das virtudes e depois dos vícios, deixando os piores escândalos para o fim (Calígula, Nero, Domiciano), de modo que a morte surge num contexto de culpa-castigo. Quanto a César, a imagem positiva do seu governo é depois bastante enegrecida pela culpa da ambição monárquica, que torna justo o seu assassínio, para voltar a ser reabilitada depois da narrativa da morte, sobretudo devido às reacções do povo e à referência ao castigo dos cesaricidas. A Vida de Cláudio é uma continua alternância de aspectos positivos e negativos, com claro pendor para os segundos, a sugerir a incongruência e incapacidade. Restam Vespasiano, cujo único vício é a pecuniae cupiditas, e Vitélio, que praticamente só tem defeitos: o primeiro mantém-se bom durante quase toda a biografia, e o segundo permanece indigno do princípio ao fim.

Porque se trata de principes, os retratos assumem uma dimensão política. Mas, na biografia, o bom ou o mau governante não é avaliado apenas pelas acções que são o objecto da história política. A sua vida é vista como um todo em que ganham especial relevo, para analiação do carácter, o pormenor da vida privada, o traço da dimensão pessoal, ilustrado com as anedotas e rumores, os hábitos alimentares, a forma de vestir e os cuidados dispensados ao corpo. 


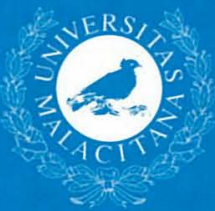

